\section{Genome resources for the stem and bark canker pathogens Corinectria fuckeliana, Neonectria hederae and N. punicea}

Catalina Salgado-Salazar ${ }^{1,2}$ and Jo Anne Crouch ${ }^{1, \dagger}$

1 U.S. Department of Agriculture, Agriculture Research Service (USDA-ARS), Mycology and Nematology Genetic Diversity and Biology Laboratory, 10300 Baltimore Avenue, Beltsville, MD, 20705, USA

${ }^{2}$ Oak Ridge Institute for Science and Education, ARS Research Participation Program, MC-100-44, P.O. Box 117, Oak Ridge, TN 37831, USA

\begin{abstract}
Corinectria fuckeliana, Neonectria hederae, and $N$. punicea are fungi in the family Nectriaceae that cause canker diseases of numerous hardwood trees, conifers, and woody perennials, often leading to plant mortality. Here, we report draft genome sequences for these three phytopathogenic fungal species. The genome sizes are consistent with those reported for other members of the Nectriaceae (28 to $43 \mathrm{Mb}$ ). These are the first genome resources available for $C$. fuckeliana, $N$. hederae, and $N$. punicea. These genome sequences may provide insights into the mechanisms of virulence and pathogenicity employed by these three destructive plant pathogens, and are resources suitable for the development of molecular markers that could be used for species identification, diagnostic tools and barcodes, and population studies.
\end{abstract}

Fungal species in the genera Corinectria and Neonectria are the causal agents of stem and bark canker diseases on a variety of hardwood and coniferous trees such as beech, birch, fir, pine, spruce, and elms, and woody evergreen perennials such as common ivy (Booth 1959; Castlebury et al. 2006; Chaverri et al. 2011; Hirooka et al. 2013). Corinectria fuckeliana, Neonectria hederae, and $N$. punicea are primarily wound invaders, requiring natural or artificial wounds for infection and colonization. However, these pathogens also exhibit different levels of virulence depending upon host type and environmental conditions (Crane et al. 2009; GómezCortecero et al. 2016; Uimari et al. 2018). C. fuckeliana cause one of the most destructive diseases of young spruce and pine plantations, orchards, and forest stands, resulting in tree mortality and increased pruning and fungicide application costs (Crane et al. 2009). Additionally, C. fuckeliana was recently found in systemic association with the moth Cydia pactolana, a serious pest of conifer forests and Christmas tree plantations, increasing the impact this disease has on forest health (Uimari et al. 2018). Neonectria punicea is often found associated with Fagus trees affected by beech bark disease caused by $N$. coccinea/ $N$. faginata (Castlebury et al. 2006), or causing collar rots on diseased ash trees affected by Hymenoscyphus fraxineus (Langer 2017). The sexual state of $N$. hederae is often found on cut ends of stems or periderm of ornamental Hedera helix (Booth 1959). Although considerable research has been devoted to the cultural management of these diseases, little is known about the population biology or genomes of these and related organisms (e.g., Gómez-Cortecero et al. 2016; Marra and Corwin 2009). Genome resources could advance understanding of disease mechanisms and underlie the development of improved tools for diagnostics, taxonomy, epidemiological, and population studies of these widespread and destructive plant pathogens.

Genomic DNA was extracted from mycelial tissue of $C$. fuckeliana G.J.S 90-31 (syn.= Nectria fuckeliana, Neonectria fuckeliana) isolated from Picea sp. in Switzerland, $N$. hederae

${ }^{\dagger}$ Corresponding author: Jo Anne Crouch; E-mail: joanne.crouch@ars.usda.gov

Mention of trade names or commercial products in this publication is solely for the purpose of providing specific information and does not imply recommendation or endorsement by the USDA. The USDA is an equal opportunity provider and employer.

Accepted for publication 21 August 2018.
Funding

This work was supported by funds from USDA-ARS project 8042-22000298-00-D and by the appointment of C. Salgado-Salazar to the ARS Research Participation Program administered by the Oak Ridge Institute for Science and Education (ORISE) through an interagency agreement between the U.S. Department of Energy (DOE) and the USDA. ORISE is managed by ORAU under DOE contract number DE-AC05-06OR23100.

\section{Keywords}

Nectriaceae, perennial canker, spruce canker 
Table 1. Summary statistics of the draft genome assemblies of Corinectria fuckeliana, Neonectria hederae, and N. punicea

\begin{tabular}{|c|c|c|c|}
\hline Species & Corinectria fuckeliana & Neonectria hederae & Neonectria punicea \\
\hline Isolate & G.J.S. 90-31 (= IMI 342667) & CBS 714.97 & CBS 119724 (= A.R. 3102) \\
\hline Herbarium no. & BPI 1107109 & BPI 871043, CBS H-6027 & BPI 871063 \\
\hline Total length (Mb) & 39.0 & 43.2 & 41.4 \\
\hline No. scaffolds & 1,399 & 508 & 1,779 \\
\hline Max. scaffold length $(\mathrm{kb})^{\mathrm{a}}$ & 462.0 & 802.0 & 342.6 \\
\hline Avg. scaffold size (kb) & 27.8 & 85.0 & 23.3 \\
\hline Average coverage & $34.3 x$ & $52.2 x$ & $24.7 x$ \\
\hline $\mathrm{N} 50(\mathrm{~kb})^{\mathrm{b}}$ & 95.9 & 248.9 & 69.9 \\
\hline GC content $(\%)$ & 52.3 & 49.4 & 52.7 \\
\hline Eukaryote orthologs ${ }^{\mathrm{c}}$ & $95.6 \%$ & $95.8 \%$ & $95.3 \%$ \\
\hline Fungal orthologs ${ }^{d^{-}}$ & $99.2 \%$ & $99.4 \%$ & $98.2 \%$ \\
\hline Predicted gene models & 11,493 & 11,966 & 13,180 \\
\hline Transposable elements $^{\mathrm{e}}$ & $1.73 \%$ & $0.52 \%$ & $0.39 \%$ \\
\hline
\end{tabular}

a Minimum scaffold length $500 \mathrm{bp}$.

b $\mathrm{N} 50=$ scaffold/contig length at which $50 \%$ of the total assembly length is covered.

c Percentage of complete BUSCOs found, 429 total BUSCO groups searched.

d Percentage of complete BUSCOs found, 1,438 total BUSCO groups searched.

e Percentage of the nuclear genome containing transposable elements.

CBS 714.97 isolated from Hedera helix in the Netherlands, and N. punicea CBS 119724 isolated from Frangula alnus in Austria, using the OmniPrep DNA kit (G-Biosciences, St. Louis, MO). These three isolates were selected for sequencing because they are well-curated representatives of each species that have been included in major taxonomic studies of the Nectriaceae (Castlebury et al. 2006; Chaverri et al. 2011). Genomic DNA libraries were constructed using the TruSeq DNA PCRfree kit and sequenced on an lllumina MiSeq as $2 \times 300$ paired-end reads using a MiSeq version 3.0 600 cycle reagent kit (Illumina, San Diego, CA). A total of 5.9, 9.4, and 4.5 million reads were obtained for $C$. fuckeliana, $N$. hederae, and $N$. punicea, respectively, after trimming for quality and to remove sequencing adapters. A de novo genome assembly was performed for all three isolates in CLC Genomics Workbench version 7 (CLC Bio, Boston, MA) using optimal settings determined through empirical testing: default settings $(\mathrm{kmer}=20$, bubble $=50)$ for $C$. fuckeliana and $N$. punicea, and $\mathrm{kmer}=50$, bubble $=36$ for $N$. hederae. A summary of the three genome assemblies is provided in Table 1. Assembly sizes of $C$. fuckeliana, $N$. hederae, and $N$. punicea were consistent with the known range of genome sizes reported to date from other species in the Nectriaceae (28 to $58 \mathrm{Mb}$; Cuomo et al. 2007; Deng et al. 2015; Gómez-Cortecero et al. 2015; Malapi-Wight et al. 2015, 2016, Rivera et al. 2018). BUSCO v3.0 (Simão et al. 2015) analyses to determine the completeness of the assemblies identified 95 to $97 \%$ and 98 to $99 \%$ of eukaryotic and fungal single-copy orthologs, respectively (Table 1). Transposable element (TE) analysis using REPET version 2.5 (Flutre et al. 2011) following the pipeline described by Rivera et al. (2018) indicated that TEs comprised just a small portion of the three genomes: $1.73 \%$ of $C$. fuckeliana, $0.52 \%$ of $N$. hederae, and $0.39 \%$ of $N$. punicea. Gene model predictions for $C$. fuckeliana, N. hederae, and N. punicea using the AUGUSTUS web server (Hoff and Stanke 2013) using Fusarium graminearum gene models identified a total of 11,493, 11,966, and 13,180 genes for C. fuckeliana, N. hederae, and N. punicea, respectively. Gene orthology analyses using OrthoVenn (http://www.bioinfogenome.net/OrthoVenn/; Wang et al. 2015) showed that the predicted proteins of these fungal species formed 10,831 orthologous clusters, of which 8,543 were shared among the three species.

The Whole Genome Shotgun projects described in this paper have been deposited at DDBJ/ENA/GenBank under accession numbers QGQC00000000 (C. fuckeliana), QGQB00000000 ( $N$. hederae), and QGQA00000000 ( $N$. punicea) (BioProject ID PRJNA472761). Voucher specimens of the fungal isolates are available at the US National Fungus Collection (BPI Herbarium) in Beltsville, MD, and the Fungal Biodiversity Institute (CBS) in Utrecht, The Netherlands (Table 1).

\section{References}

Booth, C. 1959. Studies of Pyrenomycetes. IV. Nectria (part 1). Mycol. Pap. 73:115. Castlebury, L., Rossman, A. Y., and Hyten, A. S. 2006. Phylogenetic relationships of Neonectria / Cylindrocarpon on Fagus in North America. Can. J. Bot. 84: 1417-1433.

Chaverri, P., Salgado-Salazar, C., Hirooka, Y., Rossman, A. Y., and Samuels, G. J. 2011. Delimitation of Neonectria and Cylindrocarpon (Nectriaceae, Hypocreales,
Ascomycota) and related genera with Cylindrocarpon-like anamorphs. Stud. Mycol. 68:57-78.

Crane, P. E., Hopkins, A. J. M., Dick, M. A., and Bulman, L. S. 2009. Behavior of Neonectria fuckeliana causing a pine canker disease in New Zealand. Can. J. For. Res. 39:2119-2128.

Cuomo, C. A., Güldener, U., Xu, J. R., Trail, F., Turgeon, B. G., Di Pietro, A., Walton, J. D., Ma, L. J., Baker, S. E., Rep, M., Adam, G., Antoniw, J., Baldwin, T., Calvo, 
S., Chang, Y. L., Decaprio, D., Gale, L. R., Gnerre, S., Goswami, R. S., Hammond-Kosack, K., Harris, L. J., Hilburn, K., Kennell, J. C., Kroken, S., Magnuson, J. K., Mannhaupt, G., Mauceli, E., Mewes, H. W., Mitterbauer, R., Muehlbauer, G., Münsterkötter, M., Nelson, D., O'Donnell, K., Ouellet, T., Qi, W., Quesneville, H., Roncero, M. I., Seong, K. Y., Tetko, I. V., Urban, M., Waalwijk, C., Ward, T. J., Yao, J., Birren, B. W., and Kistler, H. C. 2007. The Fusarium graminearum genome reveals a link between localized polymorphism and pathogen specialization. Science 317:1400-1402.

Deng, C. H., Scheper, R. W. A., Thrimawithana, A. H., and Bowen, J. K. 2015. Draft genome sequences of two isolates of the plant-pathogenic fungus Neonectria ditissima that differ in virulence. Genome Announc. 3:e01348-15.

Flutre, T., Duprat, E., Feuillet, C., and Quesneville, H. 2011. Considering transposable element diversification in $d$. novo annotation approaches. PLoS One 6: e16526.

Gómez-Cortecero, A., Harrison, R. J., and Armitage, A. D. 2015. Draft genome sequence of a European isolate of the apple canker pathogen Neonectria ditissima. Genome Announc. 3:e01243-15.

Gómez-Cortecero, A., Saville, R. J., Scheper, R. W. A., Bowen, J. K., Agripino De Medeiros, H., Kingsnorth, J., Xu, X., and Harrison, R. J. 2016. Variation in host and pathogen in the Neonectria/Malus interaction; toward an understanding of the genetic basis of resistance to European canker. Front. Plant Sci. 7:1365.

Hirooka, Y., Rossman, A. Y., Zhuang, W.-Y., Salgado-Salazar, C., and Chaverri, P. 2013. Species delimitation for Neonectria coccinea group including the causal agents of beech bark disease in Asia, Europe and North America. Mycosystema 32:485-517.
Hoff, K. J., and Stanke, M. 2013. WebAUGUSTUS - a web service for training AUGUSTUS and predicting genes in eukaryotes. Nucleic Acids Res. 41 (W1): W123-W128.

Langer, G. 2017. Collar rots in forest of Northwest Germany affected by ash dieback. Balt. For. 23:4-19.

Malapi-Wight, M., Salgado-Salazar, C., Demers, J., Veltri, D., and Crouch, J. A. 2015. Draft genome sequence of Dactylonectria macrodidyma, a plant-pathogenic fungus in the Nectriaceae. Genome Announc. 3:e00278-15.

Malapi-Wight, M., Salgado-Salazar, C., Demers, J. E., Clement, D. L., Rane, K. K., and Crouch, J. A. 2016. Sarcococca blight: Use of whole genome sequencing for fungal plant disease diagnosis. Plant Dis. 100:1093-1100.

Marra, R. E., and Corwin, J. A. 2009. Isolation and characterization of codominant markers for the perennial canker fungal pathogen Neonectria ditissima. Mol. Ecol. Resour. 9:906-909.

Rivera, Y., Salgado-Salazar, C., Veltri, D., Malapi-Wight, M., and Crouch, J. A. 2018. Genome analysis of the ubiquitous boxwood pathogen Pseudonectria foliicola. PeerJ 6:e5401.

Simão, F. A., Waterhouse, R. M., loannidis, P., Kriventseva, E. V., and Zdobnov, E. M. 2015. BUSCO: assessing genome assembly and annotation completeness with single-copy orthologs. Bioinformatics 31:3210-3212.

Uimari, A., Heliövaara, K., Tuba, K., Poteri, M., and Vuorinen, M. 2018. Occurrence of the moth Cydia pactolana is associated with the spruce canker fungus Neonectria fuckeliana. Scand. J. For. Res. 33:529-534.

Wang, Y., Coleman-Derr, D., Chen, G., and Gu, Y. Q. 2015. OrthoVenn: a web server for genome wide comparison and annotation of orthologous clusters across multiple species. Nucleic Acids Res. 43 (W1):W78-W84. 